OPEN ACCESS

Citation: S. Aiumsumang, S. Phimphan, C. Suwannapoom, P. Chaiyasan, W. Supiwong, A. Tanomtong (2021)Acomparative chromosome study on five Minnow fishes (Cyprinidae, Cypriniformes) in Thailand. Caryologia 74(1): 89-96. doi: 10.36253/caryologia-1017

Received: July 10, 2020

Accepted: February 10, 2021

Published: July 20, 2021

Copyright: (c) 2021 S. Aiumsumang, S. Phimphan, C. Suwannapoom, P. Chaiyasan, W. Supiwong, A. Tanomtong. This is an open access, peer-reviewed article published by Firenze University Press (http://www.fupress.com/caryologia) and distributed under the terms of the Creative Commons Attribution License, which permits unrestricted use, distribution, and reproduction in any medium, provided the original author and source are credited.

Data Availability Statement: All relevant data are within the paper and its Supporting Information files.

Competing Interests: The Author(s) declare(s) no conflict of interest.

\section{A comparative chromosome study on five Minnow fishes (Cyprinidae, Cypriniformes) in Thailand}

\author{
Surachest Aiumsumang ${ }^{1,3}$, Sumalee Phimphan ${ }^{1}$, Chatmongkon Suwan- \\ NApoom $^{2}$, Patcharaporn Chaiyasan ${ }^{3}$, Weerayuth Supiwong ${ }^{4, *}$, Alongk- \\ LOD TANOMTONG ${ }^{3,5}$ \\ ${ }^{1}$ Biology Program, Faculty of Science and Technology, Phetchabun Rajabhat University, \\ Phetchabun 67000, Thailand \\ ${ }^{2}$ Department of Fishery, School of Agriculture and Natural Resources, University of \\ Phayao, Muang, Phayao 56000, Thailand \\ ${ }^{3}$ Department of Biology, Faculty of Science, Khon Kaen University, Khon Kaen 40002, \\ Thailand \\ ${ }^{4}$ Applied Science Program, Faculty of Multidisciplinary Study, Khon Kaen University, \\ Nong Khai Campus, Muang, Nong Khai 43000, Thailand \\ ${ }^{5}$ Toxic Substances in Livestock and Aquatic Animals Research Group, Department of \\ Biology, Faculty of Science, Khon Kaen University, Khon Kaen 40002, Thailand \\ ${ }^{\star}$ Corresponding author. E-mail: supiwong@hotmail.com
}

\begin{abstract}
The cytogenetic comparisons of five Minnow species from Thailand were presented here, i.e., Devario regina, D. laoensis, Rasbora paviana, $R$. aurotaenia and Esomus metalicus. The mitotic chromosomes were prepared directly from renal cells. Conventional staining and Ag-NOR banding techniques were applied to stain the chromosomes. The results revealed that all Minnow fishes studied possessed the same diploid chromosome number $(2 n)$ as 50 chromosomes. The fundamental numbers (NF) of D. laoensis, D. regina, $R$. paviana, $R$. aurotaenia and E. metalicus are 100, 100, 98, 98, and 98 respectively. Their karyotypes composing of metacentrics-submetacentrics-acrocentrics-telocentrics were as follows: 6-12-32-0 in D. regina, 6-10-34-0 in D. laoensis, 8-16-24-2 in R. paviana, 8-16-24-2 in R. aurotaenia and 8-10-30-2 in E. metalicus. The Ag-NOR banding technique provides the nucleolar organizer regions (NORs) at subtelomeric region of the short arm chromosome in the a submetacentric or acrocentric chromosomes that are located differently in the different chromosome pairs among species.
\end{abstract}

Keywords: karyotype, Minnow, fish chromosome, Cyprinid fishes, Minnow fishes.

\section{INTRODUCTION}

Devario laoensis, D. regina, Esomus metalicus, Rasbora aurotaenia, and $R$. paviana are some species of Minnows, belonging to the family Cyprinidae (Subfamily Danioninae-Danionini). They are tropical freshwater fish of minor commercial importance, which are native in Thailand. Their distribu- 
tions include the Mekong, Chao Phraya, and Meklong Basins (Froese and Pauly 2012) and they can be easily found in large and small rivers, ponds, ditches, lakes, paddy field, and swamps. It rarely occurs in low oxygen waters (Brittan 1954, 1971, 1998). They could be used to assess if they were sensitive to change in environmental problems and aquatic pollution (Blazer 2002, Frame and Dickerson 2006, Raskovic et al. 2010, Yenchum 2010, Reddy, Rawat 2013).

The current spurt in the fish cytogenetical studies has its origin in the standardization of newer techniques and the realization of an immense applied value of the cytogenetic data of fishes. The study on fish chromosomes has received considerable attention in recent years because of their importance in classification, evolution, heredity, systematic (Gold et al. 1990, Ueda et al. 2001, Barat et al. 2002, Barat and Sahoo 2007), fish breeding, rapid production of inbred lines including cytotaxonomy (Kirpichnikov 1981) and prove the ploidy status in some sturgeons (Zhou et al. 2013). The several methods namely, conventional staining, C-banding, Ag-NOR banding, and fluorescence in situ hybridization (FISH) have been used by ichthyologists for gathering of cytogenetic information of fish (Sola et al. 2000, Kavaco et al. 2005, Zhou et al. 2013), yet each of these methods provides a different aspect of the karyotype characteristics. For example, AgNOR staining shows the regions containing the actively transcribed ribosomal RNA genes (rDNA). NORs characterization can be a cytogenetic marker for cytotaxonomic studies and has been used for studying on phylogenetic relationships among the Cyprinids (Amemyia and Gold 1988, Gatetti Jr 1998, Almeida-Toledo et al, 2000). However, cytogenetic studies conducted on this group (Devario, Esomus and Rasbora) are quite scarce. There are some karyotype reports, including Rasbora trilineata and $R$. heteromorpha: $2 n=48$ (Post 1965), R. buchanani: $2 n=50$ (Manna and Khuda-Bukhsh 1977), $R$. daniconius: $2 n=50$ (Khuda-Bukhsh et al. 1979), $R$. sumatrana: $2 n=50$ (Donsakul and Magtoon 1995), $R$. caudimaculata, $R$. myersi, $R$. paviei and $R$. retrodorsalis: $2 n=50$ (Donsakul and Magtoon 2002), $R$. aurotaenia: $2 n=50$ (Seetapan and Moeikum 2004), $R$. trilineata, $R$. heteromorpha, $R$. daniconius, $R$. borapetensis and $R$. einthovenii: $2 n=50$ (Donsakul et al. 2005), R. agilis, $R$. dorsicellata and $R$. rubrodorsalis: $2 n=50$ (Donsakul et al. 2009), E. metallicus: $2 n=50$ (Neeratanaphan et al. 2017) and $R$. einthovenii: $2 n=50$ (Yeesaem et al. 2019) (Table 1). The studies on the karyotypes help to investigate the genetic structure of aquatic animal species in each habitat, thus it can determine what species are related to each other in an accurate manner. This may help to facilitate the hybridization between them in the future for strain improvement (Sofy et al. 2008).

In the present study, we conducted chromosomal analyses using conventional staining and Ag-NOR banding techniques. The examined karyotypes of five Minnow species from Thailand belonging to three different genera (Devario, Esomus, and Rasbora); D. laoensis, D. regina and $R$. paviana were reported chromosomes characterized for the first time. The obtained results will provide useful cytogenetic information for further studies on taxonomy and evolutionary relationship of fishes.

\section{MATHERIAL AND METHODS}

\section{Chromosome preparation}

Individuals from both sexes of five analyzed Minnows were collected from various river basins in Thailand (Table 1 and Fig. 1). The fishes were transferred to

Table 1. Collection sites of the analyzed species show the sample number.

\begin{tabular}{|c|c|c|c|c|c|c|c|c|c|}
\hline \multirow[b]{2}{*}{ Species } & \multicolumn{9}{|c|}{ Number of specimens in site sampling } \\
\hline & $\begin{array}{c}\text { Mae Khong } \\
\text { Basin }\end{array}$ & $\begin{array}{c}\text { Sirindhorn } \\
\text { Peat Swamp } \\
\text { Forest }\end{array}$ & $\begin{array}{l}\text { Ping } \\
\text { Basin }\end{array}$ & $\begin{array}{l}\text { Yom } \\
\text { Basin }\end{array}$ & $\begin{array}{c}\text { Pa-Sak } \\
\text { Basin }\end{array}$ & $\begin{array}{c}\text { Chi } \\
\text { Basin }\end{array}$ & $\begin{array}{c}\text { Chao Phraya } \\
\text { Basin }\end{array}$ & $\begin{array}{c}\text { Song- } \\
\text { khram } \\
\text { Basin }\end{array}$ & $\begin{array}{c}\text { Remark with } \\
\text { Fig. } 1 .\end{array}$ \\
\hline Devario regina & $\begin{array}{l}05 \text { ㅇ } \\
06 \text { o" }\end{array}$ & $\begin{array}{l}06 \text { 웅 } \\
080^{7}\end{array}$ & - & - & - & - & - & - & Site 1 \\
\hline D. laoensis & - & - & 03 ९ $05 \overbrace{}^{7}$ & - & - & - & - & - & Site 2 \\
\hline Rasbora paviana & 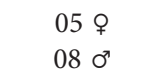 & $\begin{array}{l}03 \text { 우 } \\
040^{7}\end{array}$ & - & - & $\begin{array}{l}05 \text { 웅 } \\
07 \text { o }^{7}\end{array}$ & $\begin{array}{l}04 \text { ㅇ } \\
05 \text { O’ }^{7}\end{array}$ & - & - & Site 3 \\
\hline R. aurotaenia & - & - & - & - & - & - & $\begin{array}{l}08 \text { 웅 } \\
07 \text { o }\end{array}$ & $\begin{array}{l}05 \text { @ } \\
080^{7}\end{array}$ & Site 4 \\
\hline Esomus metalicus & - & - & - & $\begin{array}{l}04 \text { ㅇ } \\
05 \text { o }\end{array}$ & $\begin{array}{l}10 \text { 웅 } \\
100^{7}\end{array}$ & - & - & - & Site 5 \\
\hline
\end{tabular}



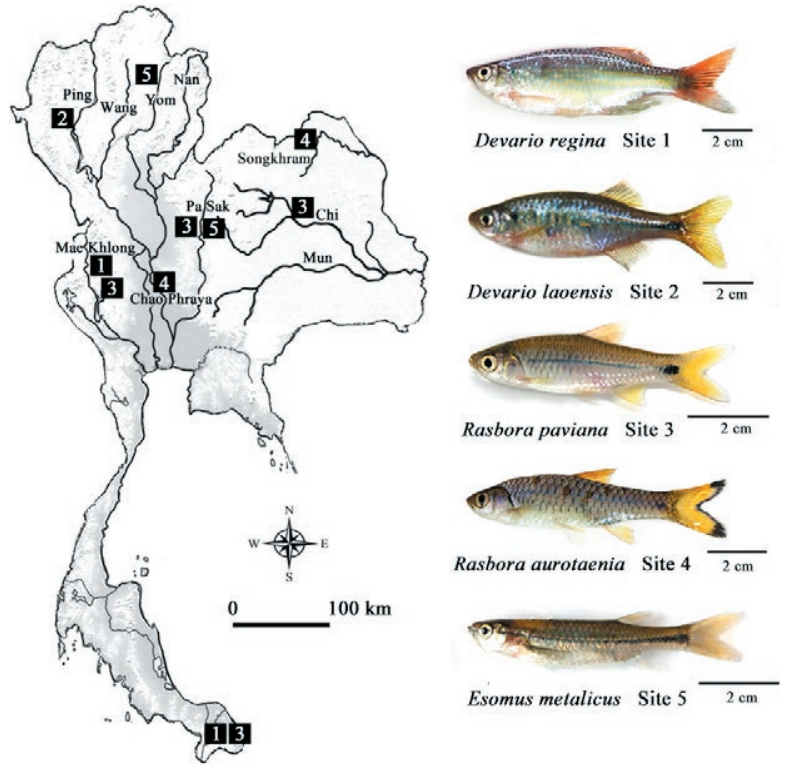

Figure 1. Collection sites of cyprinid fishes studied herein. $1=$ Devario regina, $2=$ Devario laoensis; $3=$ Rasbora paviana, $4=$ Rasbora aurotaenia, $5=$ Esomus metalicus.

laboratory aquaria and kept under standard conditions for three days before the experiments. Chromosomes were prepared in vivo as follows (Supiwong et al. 2014). The colchicine was injected into the fish's intramuscular and/or its abdominal cavity at a dose of $0.1 \mathrm{~mL} / 100$ $\mathrm{g}$ of body weight and then left for 1-2 hours. The kidney was cut into small pieces then squash mixed with 0.075 $\mathrm{M} \mathrm{KCl}$. After discarding all large piece tissues, $8 \mathrm{~mL}$ of cell sediments were transferred to a centrifuge tube and incubated for 30 minutes. The $\mathrm{KCl}$ was discarded from the supernatant after centrifugation at $1,200 \mathrm{rpm}$ for 8 minutes. Cells were fixed in fresh cool Carnoy's fixative (3 methanol: 1 glacial acetic acid) allows to preserve the internal structure of the cells for better staining of the chromosomes (Pradeep et al. 2011) to which up to $8 \mathrm{~mL}$ were gradually added before being centrifuged again at 1,200 rpm for 8 minutes, at which time the supernatant was discarded. The fixation was repeated until the supernatant was clear and the pellet was mixed with $1 \mathrm{~mL}$ fixative. The mixture was dropped onto a clean and cold slide by micropipette followed by air-drying technique.

\section{Chromosome staining}

Conventional staining was carried out using 20\% Giemsa's solution for 15 minutes (Phimphan et al. 2017). Ag-NOR banding was performed by adding 4 drops of $50 \%$ silver nitrate and $2 \%$ gelatin on slides (Howell and Black 1980). The slides were then sealed with cover glasses and incubated at $60^{\circ} \mathrm{C}$ for 5 minutes. After that, the slides were soaked in distilled water until the cover glasses were separated. Then, they were stained with $20 \%$ Giemsa's solution for 1 minute.

\section{Chromosome check and Image processing}

Twenty clearly observable metaphase cells with a well-spread chromosome of each male and female were selected. Images were captured under a light microscope Nikon ECLIPSE by a digital CCD camera (Nikon DSFi1). The chromosomes were classified based on the position of a centromere as metacentric $(\mathrm{m})$, submetacentric $(\mathrm{sm})$, acrocentric (a), telocentric $(\mathrm{t})$ according to the arm ratios (Chaiyasut 1989).

\section{RESULTS}

Five minnow fishes were similar in the diploid number of $2 n=50$, with the karyotype composed of $\mathrm{m} 6+\mathrm{sm} 12+\mathrm{a} 32$ in $D$. regina. The mean values calculated from twenty mitotic metaphases showed the relative length (RL) of chromosomes complement ranging from $0.041 \pm 0.010$ to $0.033 \pm 0.004$. The NOR was found on the short arm of chromosome pair 15 (Fig. $2 \mathrm{~A})$. The chromosome complements of $D$. laoensis consisting of $\mathrm{m} 6+10 \mathrm{sm}+34 \mathrm{a}$. The mean value of relative length ranged from $0.0 .44 \pm 0.005$ to $0.030 \pm 0.002$. The NOR was presented on the short arms of chromosome pair 11 (Fig. 2B). Karyotype of $R$. paviana composes of $8 m+16 s m+24 a+2 t$. The present investigation in this fish species revealed that the mean value of RL from $0.048 \pm 0.001$ to $0.032 \pm 0.004$. Ag-NOR banding result showed that NOR-bearing chromosomes locate at subtelomeric on the short arm of chromosome pair 9 (Fig. 2C). The karyotypic analysis result revealed that the chromosome complements of $R$. aurotaenia consisting of $8 \mathrm{~m}+16 \mathrm{sm}+24 \mathrm{a}+2 \mathrm{t}$. The parameters of all chromosomes were measured and it showed the mean value of RL from $0.0 .054 \pm 0.003$ to $0.033 \pm 0.002$. The result of silver-staining exhibited the NORs show that it locates) at short arm of chromosome pair 23 (Fig. 2D). The karyotype of E. metalicus consisting of $8 \mathrm{~m}+10 \mathrm{sm}+30 \mathrm{a}+2 \mathrm{t}$. The mean value of RL from $0.0 .51 \pm 0.001$ to $0.025 \pm 0.002$. The NOR was presented on the short arms of chromosome pair 7 (Fig. 2E). 


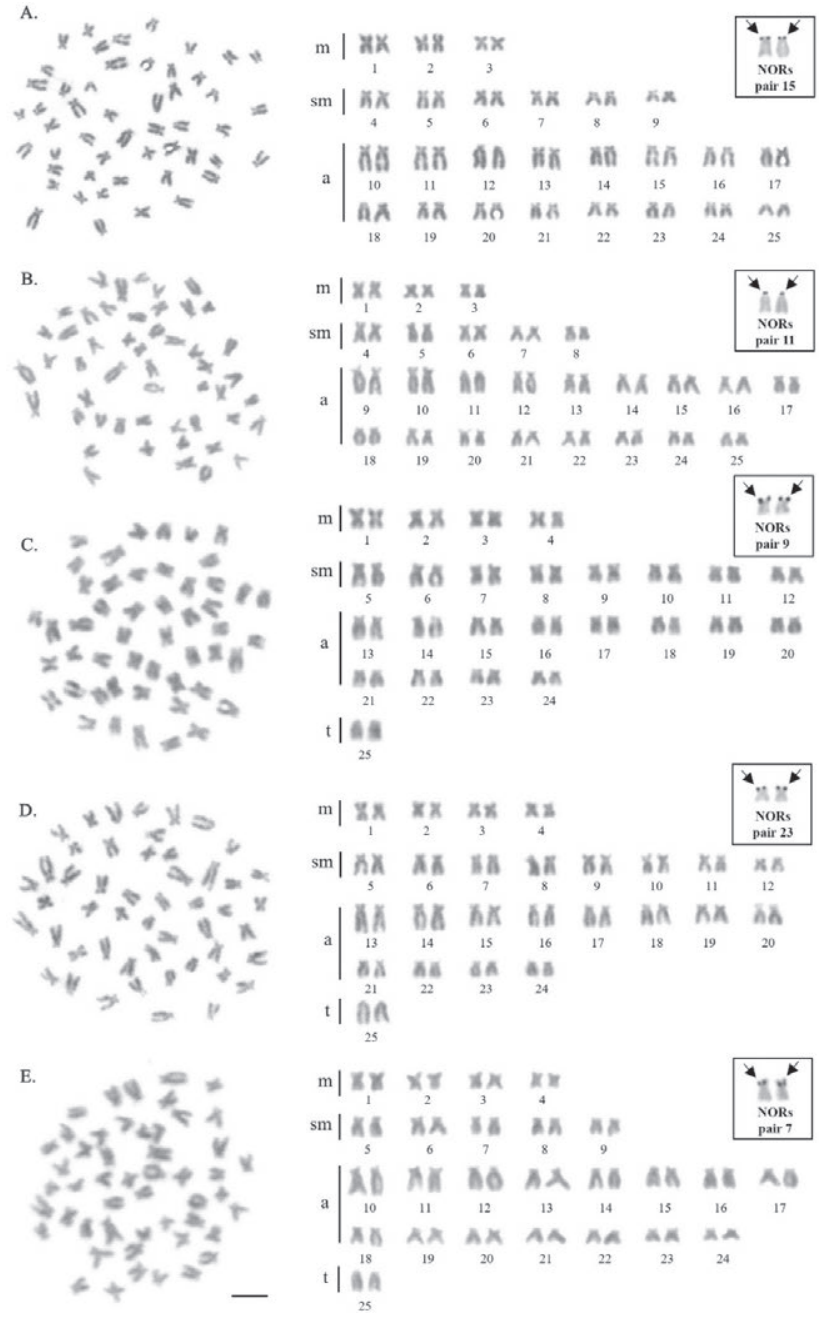

Figure 2. Metaphase chromosome plates and karyotypes of the Devario regina (A.), D. laoensis (B.), Rasbora paviana (C.), R. aurotaenia (D.) and Esomus metalicus (E.), by conventional staining. The arrows indicate NOR banding by Ag-NOR staining technique (inserted box). All species share the karyotype composed of 50 chromosomes. Scale bar indicates $5 \mu \mathrm{m}$.

\section{DISCUSSION}

The details of each metaphase chromosome spread and karyotype of five Minnow fishes, including D. regi$n a, D$. laoensis, $R$. paviana, $R$. aurotaenia, and E. metalicus are shown in Figure 2. The present study is the first report on the chromosomal characteristics of D. laoensis, $D$. regina, and $R$. paviana determined using conventional staining and Ag-NOR banding techniques. The diploid chromosome number of all species provided 50 chromosomes, which is shared by most of the cyprinid species previously analyzed (Post 1965, Manna and Khuda-Bukhsh 1977, Khuda-Bukhsh et al. 1979, Donsakul and Magtoon 1995, Donsakul and Magtoon 2002, Seetapan and Moeikum 2004, Donsakul et al. 2005, Donsakul et al. 2009, Neeratanaphan et al. 2017, Yeesaem et al. 2019) (Table 2). The NFs of $D$. laoensis and D. regina are 100 equally, while those of $R$. paviana, $R$. aurotaenia, and E. metalicus are equal to 98 in both sexes. To compare with previous studies, they are differences from Seetapan and Moeikum (2004) who reported the NF=92 in $R$. aurotaenia and Neeratanaphan et al. (2017) showed the NF of E. metallicus as 100. The differences in NF values are caused by the difference in the number of monoarm chromosomes. This phenomenon may be resulting from the intra-specific variation between populations of those species. This finding is in agreement with other species such as $R$. daniconius (Khuda-Bukhsh et al. 1979, Donsakul et al. 2005), R. einthovenii (Donsakul et al. 2005, Yeesaem et al. 2019), and $R$. rebrodorsalis (Donsakul and Magtoon 2002, Donsakul et al. 2009). The NF of these genera varied from 74 to 100 (Table 2). All species were analyzed herein display without morphologically differentiated sex chromosomes. This character is the same as in previous studies of this family (Arai 2011).

Although five Minnows analyzed herein have the same diploid number, there are differences in karyotype complements as follows (Fig. 2). D. regina has six metacentric (m) (pairs 1-3), 12 submetacentric (sm) (pairs 4-9) and 32 acrocentric (a) (pairs 10-25) chromosomes. The mean values were calculated from twenty mitotic metaphases showed the centromeric index (CI) of chromosome complements ranging from $0.548 \pm 0.004$ to $0.808 \pm 0.005$. The karyotype formula of $D$. regina could be deduced as $2 n(50)=6 \mathrm{~m}+12 \mathrm{sm}+32 \mathrm{a}$. D. laoensis has six metacentric (pairs 1-3), 10 submetacentric (pairs 4-8) and 34 acrocentric (pairs 9-25) chromosomes. The mean values of CI ranged from $0.553 \pm 0.005$ to $0.798 \pm 0.002$. The karyotype formula of this species is $2 n(50)=$ $6 \mathrm{~m}+10 \mathrm{sm}+34 \mathrm{a}$. R. paviana consisted of eight metacentrics (pairs 1-4), 16 submetacentrisc (pairs 5-12), 24 acrocentrics (pairs 13-24) and two telocentrics (t) (pair 25). The mean values of CI ranged between $0.526 \pm 0.002$ and $1.000 \pm 0.000$. The proposed karyotype of this species was $2 n(50)=8 \mathrm{~m}+16 \mathrm{sm}+24 \mathrm{a}+2 \mathrm{t}$. $R$. aurotaenia shows eight metacentrics (pairs 1-4), 16 submetacentrics (pairs 5-12), 24 acrocentrics (pairs 13-24) and two telocentrics (pair 25) chromosomes. The mean values of $\mathrm{CI}$ in this species ranged from $0.569 \pm 0.003$ to $1.000 \pm 0.000$. The karyotype of this species was $2 n(50)=8 \mathrm{~m}+16 \mathrm{sm}+24 \mathrm{a}+2 \mathrm{t}$, which differs from the previous study by Seetapan and Moeikum (2004) that reported the karyotype of this species consisting of $2 n(50)=14 \mathrm{~m}+26 \mathrm{sm}+2 \mathrm{st}+8 \mathrm{a}$. In E. metalicus, the karyotype composed of eight metacentric (pairs 
Table 2. Cytogenetic reported of the genera Devario, Esomus and Rasbora.

\begin{tabular}{|c|c|c|c|c|c|c|}
\hline Species & $2 n$ & $\mathrm{NF}_{1}$ & $\mathrm{NF}_{2}$ & Karyotype formula & NOR & Reference \\
\hline Devario laoensis & 50 & 100 & 66 & $6 m+10 s m+34 a$ & 2 & Present study \\
\hline D. regina & 50 & 100 & 68 & $6 m+12 s m+32 a$ & 2 & Present study \\
\hline \multirow[t]{2}{*}{ Esomus metallicus } & 50 & 100 & 86 & $14 m+22 s m+14 a$ & - & Neeratanaphan et al. (2017) \\
\hline & 50 & 98 & 68 & $8 m+10 s m+30 a+2 t$ & 2 & Present study \\
\hline Rasbora agilis & 50 & 100 & 100 & $24 m+26 s m$ & - & Donsakul et al. (2009) \\
\hline \multirow[t]{2}{*}{ R. aurotaenia } & 50 & 92 & 90 & $14 m+26 s m+2 a+8 t$ & & Seetapan and Moeikum (2004) \\
\hline & 50 & 98 & 74 & $8 m+16 s m+24 a+2 t$ & 2 & Present study \\
\hline R. borapetensis & 50 & 88 & 88 & $24 m+14 s m+12 t$ & - & Donsakul et al. (2005) \\
\hline R. buchanani & 50 & 100 & 96 & $30 \mathrm{~m}+18 \mathrm{sm}+2 \mathrm{a}$ & - & Manna and Khuda-Bukhsh (1977) \\
\hline R. caudimaculata & 50 & 98 & 96 & $20 m+26 s m+2 a+2 t$ & - & Donsakul and Magtoon (2002) \\
\hline R. daniconius & 50 & 80 & 74 & $18 \mathrm{~m}+6 \mathrm{sm}+6 \mathrm{a}+20 \mathrm{t}$ & - & Khuda-Bukhsh et al. (1979) \\
\hline R. daniconius & 50 & 92 & 90 & $32 \mathrm{~m}+8 \mathrm{sm}+2 \mathrm{a}+8 \mathrm{t}$ & - & Donsakul et al. (2005) \\
\hline R. dorsicellata & 50 & 92 & 92 & $18 m+24 s m+8 t$ & - & Donsakul et al. (2009) \\
\hline \multirow[t]{2}{*}{ R. einthovenii } & 50 & 94 & 86 & $6 m+30 s m+8 a+6 t$ & - & Donsakul et al. (2005) \\
\hline & 50 & 100 & 84 & $16 m+18 s m+16 a$ & 2 & Yeesaem et al. (2019) \\
\hline \multirow[t]{2}{*}{ R. heteromorpha } & 48 & - & - & - & - & Post (1965) \\
\hline & 48 & 74 & 72 & $14 \mathrm{~m}+10 \mathrm{sm}+2 \mathrm{a}+22 \mathrm{t}$ & - & Donsakul et al. (2005) \\
\hline R. myersi & 50 & 90 & 84 & $20 m+14 s m+6 a+10 t$ & - & Donsakul and Magtoon (2002) \\
\hline R. paviei & 50 & 100 & 84 & $10 m+24 s m+16 a$ & - & Donsakul and Magtoon (2002) \\
\hline R.paviana & 50 & 98 & 74 & $8 m+16 s m+24 a+2 t$ & 2 & Present study \\
\hline R. retrodorsalis & 50 & 88 & 86 & $26 m+10 s m+2 a+12 t$ & - & Donsakul and Magtoon (2002) \\
\hline R. rubrodorsalis & 50 & 82 & 82 & $16 m+16 s m+18 t$ & - & Donsakul et al. (2009) \\
\hline R. sumatrana & 50 & 94 & 92 & $26 \mathrm{~m}+16 \mathrm{sm}+2 \mathrm{a}+6 \mathrm{t}$ & - & Donsakul and Magtoon (1995) \\
\hline R. trilineata & 48 & - & - & - & - & Post (1965) \\
\hline R. trilineata & 50 & 94 & 92 & $26 \mathrm{~m}+16 \mathrm{sm}+2 \mathrm{a}+6 \mathrm{t}$ & - & Donsakul et al. (2005) \\
\hline
\end{tabular}

Abbreviations: diploid chromosome number $(2 n)$, fundamental number $\mathrm{m}, \mathrm{sm}, \mathrm{a}=2, \mathrm{t}=1(\mathrm{NF} 1)$, fundamental number $\mathrm{m}, \mathrm{sm},=2, \mathrm{a}, \mathrm{t}=1$ $(\mathrm{NF} 2)$, metacentric $(\mathrm{m})$, submetacentric $(\mathrm{sm})$, acrocentric (a), telocentric (t), Nucleolar Organizer Region (NOR).

1-4), 10 submetacentric (pairs 5-9), 30 acrocentric (pairs 10-24), and two telocentric (pair 25) chromosomes. The mean values of CI ranged between $0.558 \pm 0.003$ and $1.000 \pm 0.000$. The karyotype of $E$. metalicus showed $2 n(50)=8 \mathrm{~m}+10 \mathrm{sm}+30 \mathrm{a}+2 \mathrm{t}$. These results are inconsistent with previous cytogenetic data (Neeratanaphan et al. 2017). This fact suggests that some pericentric inversions have occurred in the karyotype differentiation of this species. Besides), the occurrence of chromosomal rearrangements has been considered a relatively common evolutionary mechanism inside the Cyprinidae family reviewed (Arai 2011). Family Cyprinidae are diploid chromosome ranges from $48-50$ in the tribes Labeoni$n i$ and Smiliogastrini while the tribe Poropuntiini and Danionini are more conserved as $2 \mathrm{n}=50$ (Phimphan et al. 2020).
Karyotype diversification processes in species are subjected to multiple factors, whether intrinsic (genomic or chromosomal particularities) or extrinsic (historic contingencies) factor. Among these, restricted gene flow between populations is an important factor for the fixation of karyotype changes. For example, after the occurrence of an inversion, it can be lost in the polymorphic state or, under the proper conditions, spread in the population until it is fixed. Inversions maintain areas of imbalance between alleles in loci within or influenced by these rearrangements, leading to an adaptive condition, primarily along environmental gradients. This could occur, particularly concerning possible historical expansion and adaptation to new environments for a review Hoffmann (2008). As mention above, the chromosomal study is very important and clearly exhibits the benefits. 
Moreover, the karyological and NORs characteristics in cyprinid fishes were reported in some species.

The present study is the first report on the NOR phenotypes in five Minnow species studied. The single pair of NOR-bearing chromosomes were observed at subtelomeric regions on the short arm chromosomes in all species analyzed. However, there are differences in chromosome types and pair numbers as follows. The NORs were observed on acrocentric chromosome pair 15 in D. regina whereas those were found on acrocentric chromosome pair 11 in D. laoensis. In the genus Rasbora, the NORs located on the submetacentric chromosome pair 9 in $R$. paviana and distinct revealed on the acrocentric chromosome pair 23 in $R$. aurotaenia. For E. metalicus, NOR-baring chromosomes were found on the submetacentric chromosome pair 7 (Fig. 2). To compare with the same genus in previous report, $R$. einthovenii has single pair of NOR on chromosome pair 4 (Yeesaem et al. 2019). Moreover, the single pair of NOR bearing chromosomes can be observed in other cyprinids such as Aspius aspius (Ràb et al. 1990), Osteochilus waandersi (Magtoon and Arai 1993), Barbonymus gonionotus (Khuda-Bukhsh and Das 2007), Puntioplites proctozysron (Supiwong et al. 2012), Puntius brevis (Nitikulworawong and Khrueanet 2014). Also, the subtelomeric region of chromosome pair showed clearly observable NORs in most cyprinid fishes. However, NOR variation can be revealed in among populations of the same species as found in Garra rufa. This variation is caused by geographically isolated populations (Arzu and Ergene 2009). Normally, most fishes have only one pair of small NORs on chromosomes. Only some fishes have more than two NORs, which may be caused by the translocation between some parts of the chromosomes that have NOR and another chromosome (Sharma et al. 2002). Our present study showed that the species analyzed had a NOR site on a single chromosome pair at a subtelomeric position. This is considered a simple condition in fish (Almeida-Toledo 1985).

In the present study, five Minnows belong to genera of which have closely related species. The obtained results have shown that this fish group shares the same $2 n$. However, there are differences in karyotype complements and NOR-bearing chromosome markers. These seem to be that cytogenetic methods can be used for the systematics of this fish family.

\section{ACKNOWLEDGMENTS}

The authors are grateful to Phetchabun Rajabhat University and Toxic Substances in Livestock and Aquat- ic Animals Research Group Khon Kaen University and Unit of Excellence 2020 on Biodiversity, Natural Resources Management, University of Phayao (UoE63005) and the Post-Doctoral Training Program from Research Affairs and Graduate School, Khon Kaen University, Thailand (Grant no. 59255) for financial supports.

\section{REFERENCES}

Amemiya CT, Gold JR. 1988. Chromosomal NORs as taxonomic and systematic characters in North American cyprinid fishes. Genetica 76: 81-90. https://doi. org/10.1007/BF00058806

Almeida-Toledo LF. 1985. The nucleolar organizer regions in fish. Science Culture 37: 448-453. (in Portuguese)

Almeida-Toledo LF, Foresti F, Toledo-Filho SA. 2000. Karyotypic evolution in neotropical freshwater fish. Chromosome Today 13: 169-181. https://doi. org/10.1007/978-3-0348-8484-6_13

Arai R. 2011. Fish karyotype a check list. Japan: Springer press.

Arzu K, Ergene S. 2009. Cytogenetic Variation of Geographically Isolated Four Populations of Garra rufa [(Heckel, 1843) (Pisces, Cyprinidae)] in Turkey, Caryologia 62: 276-287.

Barat A, Sahoo PK. 2007. Karyotype analysis of Channa punctatus (Pisces) using restriction endonucleases. Cytologia 72: 471-473.

Barat A, Sahoo PK, Ponniah AG. 2002. Karyotype and Nucleolar Organizer Regions (NORs) in a Few Hill Stream Fishes. In: Ayyappan S, Jena JK, Joseph MM (eds.). The Fifth Indian Fisheries Forum Proceedings, AFSIB, Mangalore and AoA, Bhubaneswar. pp. $111-114$

Blazer VS. 2002. Histopathological assessment of gonadal tissue in wild fishes. Physiol. Biochem. 26: 85-101.

Brittan MR. 1954. A revision of the Indo-Malayan freshwater fish genus Rasbora. Inst. Sci. Technol. Manila Monogr 3: 1-224.

Brittan MR. 1971. Rasbora: A Revision of the IndoMalayan Fresh-Water Fish Genus Rasbora. T.F.H. Publications, Neptune City.

Brittan MR. 1998. Rasboras: Keeping and Breeding Them in Captivity. T.F.H. Publications, Neptune City.

Chaiyasut K. 1989. Cytogenetics and Cytotaxonomy of the Family Zephyranthes. Department of Botany, Faculty of Science, Chulalongkorn University, Bangkok.

Donsakul T, Magtoon W, Rangsiruji W. 2005. Karyotype of five species of fish (Pla siew) in subfamily Rasbo- 
ranae. $31^{\text {st }}$ Congress on Science and Technology of Thailand at Suranaree University of Technology. Nakhon Ratchasima Province Thailand.

Donsakul T, Magtoon W. 1995. Karyotypes of four Cyprinid fishes, Osteochilus melanopleura, Puntioplites proctozysron, Paralaubuca riveroi and Rasbora sumatrana from Thailand. In: $33^{\text {rd }}$ Conference of Kasetsart University. Fisheries. 128-138. [In Thai]

Donsakul T, Magtoon W. 2002. Karyotype of Rasbora Caudimaculata, R. myersi, $R$. retrodorsalis, R. paviei from Thailand. Academic conference seminar for research papers of Srinakharinwirot University. Bangkok. 1-7. [In Thai]

Donsakul T, Rangsiruji A, Magtoon W. 2009. Karyotypes of five cyprinid fishes (Cyprinidae, Danioninae-Danionini): Rasbora agilis, $R$. dorsiocellata, $R$. rubrodorsalis, Boraras maculate and B. urophthalmoides from Thailand. In Proceedings of the $47^{\text {th }}$ Kasetsart University Annual Conference, Kasetsart. Bangkok, Thailand. 320-327.

Froese R, Pauly D (Eds.) 2012: Fish Base. World Wide Web electronic publication, www.fishbase.org, version $06 / 2019$.

Fram L, Dickerson RL. 2006. Fish and wildlife as sentinels of environment contamination. In Endocrine disruption: biological bases for health effects in wildlife and humans. Oxford University Press, New York, U.S.A.

Galetti PM Jr. 1998. Chromosome diversity in neotropical fish: NOR studies. Ital J Zool. 65 sup1: 53-6.

Gold JR, Li YC, Shipley NS, Powers PK. 1990. Improved methods for working with fish chromosomes with a review of metaphase chromosome banding. J Fish Biol. 37: 563-575.

Hoffmann AA, Rieseberg LH. 2008. Revisiting the impact of inversions in evolution: from population genetic markers to drivers of adaptive shifts and speciation? Annu. Rev. Ecol. Evol. Syst. 39: 21-42.

Howell WM, Black DA. 1980. Controlled silver staining of nucleolus organizer regions with a protective colloidal developer: a 1-step method. Experientia 36: 1014-1015.

Kavaco KF, Pazza R, Bertollo LAC, Moreira-Filho O. 2005. Molecular cytogenetics of Oligosarcus hepsetus (Teleotei, Chareciformes) from two Brazilian locations. Genetics 124: 85-91.

Khuda-Bukhsh AR. 1979. Karyology of two species of hillstream fishes, Barilius bendelisis and Rasbora daniconius (Fam. Cyprinidae). Current Sci. 48: 793-794.

Khuda-Bukhsh AR, Das JK (2007). Cytogenetic analyses in eight species of teleostean fishes (Pisces): karyotypes, multiple Ag-NORs, sex chromosomes. Research and Reviews in Bio Sci. (India) 1: 47-52.
Kirpichnikov VS. 1981. Genetic Bases of Fish Selection. Springer Verlag, New York.

Magtoon W, Arai R. 1993. Karyotypes and distribution of nucleolus organizer regions in cyprinid fishes from Thailand. JPN J Ichthyol. 40: 77-85. https://doi. org/10.11369/jji1950.40.77

Manna GK, Khuda-Bukhsh AR. 1977. Karyomorphology of cyprinid fishes and cytological evaluation of the family. Nucleus 20: 119-127.

Neeratanaphan L, Khamlerd C, Chowrong S, Intamat S, Sriuttha M, Tengjaroenkul B. 2017. Cytotoxic assessment of flying barb fish (Esomus metallicus) from a gold mine area with heavy metal contamination. Int J Environ. Sci. 17: 6 https://doi.org/10.1080/0020723 3.2017.1341196.

Nitikulworawong N, Khrueanet W. 2014. Karyotypic of golden little barb, Puntius brevis Bleeker, 1850 (Pisces: Cyprinidae) from Khon Kaen Province. KKU Sci. J 42: 106-118.

Pradeep JP, Srijaya CT, Zain MBR, Papini A, Chatterji KA. 2011. A Simple Technique for Chromosome Preparation from Embryonic Tissues of teleosts for Ploidy Verification. Caryologia 64(2): 235-241. https://doi.org/ 10.1080/00087114.2002.10589788

Phimphan S, Supiwong W, Tanomtong T, Pinthong K, Sangpakdee W, Kaewsri S. 2017. Karyotypic Study of Five Lutjanid Species Using Conventional and AgNORs Banding Techniques. Cytol. Genet. 51: 315-324.

Phimphan S, Chaiyasan P, Suwannapoom C, Reungsing M, Juntaree S, Tanomtong A, Supiwong A. 2020. Comparative karyotype study of three Cyprinids (Cyprinidae, Cyprininae) in Thailand by classical cytogenetic and FISH techniques. Comp. Cytogen. 14(4): 597-612. https://doi.org/10.3897/CompCytogen.v14i4.54428

Post A. 1965. Vergleichede Untersuchungen der chromosomenzahlen bei Susswasser-Teleosteern. In: Gyldenholm AO, Scheel JJ. Chromosome number of fishes I. J Fish Biol. 3: 47-93.

Raskovic B, Poleksic V, Zivic I, Spasic M. 2010. Histology of carp (Cyprinus carpio, L.) gills and pond water quality in semiintensive production. Bulg. J Agric Sci 16: 253-262.

Ràb P, Roth P, Arefjev VA. 1990. Chromosome Studies of European Leuciscine Fishes (Pisces Cyprinidae). Karyotype of Aspius Aspius. Caryologia 43: 249-255. https://doi.org/10.1080/00087114.1990.10797003

Reddy PB, Rawat SS. 2013. Assessment of aquatic pollution using histopathology in fish. Int J Environ. Sci. 2: 79-82.

Seetapan K, Moeikum T. 2004. Karyotypes of ten Cyprinid fishes (Family Cyprinidae). J Agric. Ext. 22: 92-101. [in Thai] 
Sharma OP, Tripathi NK, Sharma KK. 2002. A review of chromosome banding in fishes. In: Sobti RC, Obe G (eds.). Some Aspects of Chromosome Structure and Functions. Narosa Publishing House, New Delhi.

Sofy HI, Layla AM, Iman MKA. 2008. Karyotypic diversity of some tilapia species. Nature and Science 6(1): 19-27.

Sola L, De Innocentiis S, Gornung E, Papalia S, Rossi AR, Marino G, De Marco P, Cataudella S. 2000. Cytogenetic analysis of Epinephelus marginatus (Pisces: Serranidae), with the chromosome localization of the $18 \mathrm{~S}$ and 5S rRNA genes and of the (TTAGGG)n telomeric sequence. Marine Biol. 137: 47-51.

Supiwong W, Liehr T, Cioffi BM, Chaveerach A, Kosyakova N, Pinthong K, Tanee T, Tanomtong A. 2014. Chromosomal evolution in naked catfishes (Bagridae, Siluriformes): A comparative chromosome mapping study. Zoologischer Anzeiger 253: 316-320.

Supiwong W, Tanomtong A, Supanuam P, Jantarat P, Khakhong S, Sanoamuang L. 2012. A discovery of nucleolar organizer regions (NORs) polymorphism and karyological analysis of Smith's Barb, Puntioplites proctozysron (Cypriniformes, Cyprinidae) in Thailand. Cytologia 77: 35-42.

Ueda T, Naoi H, Arai R. 2001. Flexibility on the karyotype evolution in bitterlings (Pisces, Cyprinidae). Genetica 111: 423-432.

Yenchum W. 2010. Histological effects of carbofuran on guppy Poecilia reticulata Peters. Ph.D Thesis in Biological Science, Chulalongkorn University, Bangkok, Thailand.

Yeesaem N, Jantarat S, Yeesin P. 2019. Cytogenetic Characterigation of Rasbora einthovenii in Sirindhorn Peat Swamp Forest, Narathiwat Province. J Fish Tech. Res. 13: 58-68.

Zhou H, Fujimoto T, Adachi S, Abe S, Yamaha E, Arai K. 2013. Molecular cytogenetic study on the ploidy status in Acipenser mikadoi. J Appl. Ichthyol. 29: 51-55. 